\title{
Environmental temperature and broiler age on corn energy value
}

\section{Temperatura ambiente e idade do frango de corte sobre o valor energético do milho}

Fabyola Barros Carvalho ${ }^{*}$ (D) , José Roberto Sartori ${ }^{2}$ (D) , Antonio Celso Pezzato ${ }^{2}$ (D) , Vitor Barbosa Fascina $^{2}$ (D), Pedro Gibim Castelo ${ }^{2}$ (D) , Ivan Mailinch Gonçalves Pereira de Souza ${ }^{2}$

${ }^{1}$ Universidade Federal de Goiás, Goiânia, Brazil.

2Universidade Estadual Paulista, Botucatu, São Paulo, Brazil.

*Correspondent - fabyolab@hotmail.com

Received

September 8, 2020

Accepted

January 18, 2021.

Published

May 05, 2021.

www.revistas.ufg.br/vet

visit the website to get the

how to cite in the article page.

\section{Abstract}

This study aimed to assess the effects of environmental temperature and age of broilers on the energy value of corn. A total of 288 Cobb 500 chicks were distributed in a complete randomized design with a split-plot arrangement and six replications of six chicks each. The main plot consisted of three temperatures (cold: $18{ }^{\circ} \mathrm{C}$; thermoneutral: $25^{\circ} \mathrm{C}$; and hot: $33^{\circ} \mathrm{C}$ ), while the secondary plot consisted of age (initial: 11 to 14 days; growing: 25 to 28 days; and final: 39 to 42 days). The basal diet was based on corn and soybean meal. The test diet was produced by replacing the basal diet for test food: $40 \%$ corn $+60 \%$ basal diet. The mean values of AMEn observed for broiler chicks under cold, thermoneutral, and hot temperatures were 3322, 3279, and $3233 \mathrm{kcal} / \mathrm{kg}$ of natural matter, respectively, and 3215, 3218, and $3400 \mathrm{kcal} /$ $\mathrm{kg}$ of natural matter for the initial, growing, and final phases, respectively. Overall, the metabolizable energy values of corn and the balance and coefficients of metabolizability of nutrients in the test diet increased with the broiler age, but the true metabolizable energies of corn were not affected by environmental temperature. The balance and coefficients of metabolizability of nutrients in the test diet decreased due to heat exposure during the growing and final phases.

Keywords: nitrogen balance; metabolizable energy; heat stress; cold stress; metabolizability of nutrients.

\section{Resumo}

Oobjetivo destetrabalho foideterminaro efeito datemperatura ambiente e da idade da ave sobre o valor energético do milho. Foram utilizados 288 pintos de corte, da linhagem Cobb 500, distribuídos em delineamento experimental inteiramente casualizado em esquema de parcelas subdivididas no tempo, sendo as parcelas as três temperaturas de criação (fria: 18 ${ }^{\circ} \mathrm{C}$; termoneutra: $25^{\circ} \mathrm{C}$ e quente: $33^{\circ} \mathrm{C}$ ) e as subparcelas as três idades de avaliação (inicial: 11 a 14; crescimento: 25 a 28 e final: 39 a 42 dias), com seis repetições de seis aves cada. A dieta basal foi composta por milho e farelo de soja. A dieta 
teste foi produzida substituindo a dieta basal pelo alimento teste: $40 \%$ de milho $+60 \%$ da dieta basal. Encontraram-se valores médios de energia metabolizável aparente, corrigida pelo balanço de nitrogênio (EMAn) do milho, para aves criadas em $18^{\circ} \mathrm{C} ; 25^{\circ} \mathrm{C}$ e $33^{\circ} \mathrm{C}$ de 3322 , 3279 e $3233 \mathrm{kcal} / \mathrm{kg}$ de matéria natural, respectivamente, e para as fases de 11 a 14; 25 a 28 e 39 a 42 dias de 3215, 3218 e $3400 \mathrm{kcal} / \mathrm{kg}$ de matéria natural, respectivamente. De um modo geral, os valores de energia metabolizável do milho, os balanços e os coeficientes de metabolizabilidade dos nutrientes da dieta teste aumentam com a idade do frango de corte, porém as energias metabolizáveis verdadeiras do milho não foram afetadas pela temperatura ambiente. Os balanços e os coeficientes de metabolizabilidade dos nutrientes da dieta teste foram reduzidos em estresse por calor para aves na fase de crescimento e final.

Palavras-chave: balanço de nitrogênio; energia metabolizável; estresse por calor; estresse por frio; metabilizabilidade de nutrientes.

\section{Introduction}

The nutritional composition of ingredients and their respective energy values must be as accurate as possible in feed formulation, justifying the determination of the chemical composition and metabolizable energy values of national foods commonly used in animal nutrition.

The update of nutrient requirements in feed formulations is important because of the productivity and maintenance of broilers, which are altered due to genetic improvement and other factors, such as age, sex, lines, and environmental temperature, ${ }^{(1)}$ which modify the use of energy and protein.

Corn is the main energy ingredient in poultry feed, but it also contributes a good part to dietary protein. It is responsible for approximately $25 \%$ of the total crude protein in chicken diets, ${ }^{(2)}$ with its greatest limitation, as a source of nutrients, the low content of the amino acids lysine and tryptophan.

The determination of the metabolizable energy values of ingredients considering the age may contribute to the caloric adequacy of diets. The digestive capacity of the poultry increases as their age advances, with increased use of nutrients due to the development of accessory organs and the digestive system..$^{(3)}$ Thus, the formulation using the metabolizable energy values of the food adjusted to the poultry age can lead to a higher optimization in the formulation and less waste of nutrients in the feed, improving feed conversion and, consequently, decreasing the food cost.

In general, the recommendations on nutrition and feeding of broilers are carried out at an environmental temperature within the comfort range of growing poultry, which is not adequate to meet their energy requirements in a heat or cold stress environment, which may be one of the causes for the decrease in broiler performance. 
Considering that poultryvoluntarily reduce food intake as the environmental temperature rises above the thermal comfort range, ${ }_{(}^{(4)}$ a feed formulated for thermoneutral conditions would not be adequate to meet their energy requirements in a heat-stress environment.

This study was developed to determine the effect of the environmental temperature and broiler age on the energy value of corn.

\section{Material and methods}

The experiment was conducted at the School of Veterinary Medicine and Animal Science, UNESP, campus of Botucatu, at the Laboratory of Poultry Nutrition, according to the ethical principles in animal experimentation approved by the Committee on Ethics in Animal Experimentation (Protocol No. 160/2007-CEEA). A total of 288 male Cobb 500 broiler chicks were used. The experimental design was completely randomized in a split-plot scheme in time, with the plots consisting of three temperatures $(18,25$, and $33^{\circ} \mathrm{C}$ ) and the subplots consisting of three ages of assessment (initial: 11 to 14 days; growth: 25 to 28 days; and final: 39 to 42 days), with six replications of six animals.

A total of 216 out of the 288 broiler chicks were distributed in 36 galvanized wire cages, measuring $0.50 \mathrm{~m}$ high, $0.50 \mathrm{~m}$ wide, and $0.60 \mathrm{~m}$ deep, distributed in three temperaturecontrolled chambers (hot, thermoneutral, and cold) with the cages arranged in two batteries of two floors each, totaling 12 cages/chamber. The remaining 72 broiler chicks were used in an extra treatment (fasting for 72 hours) to assess endogenous and metabolic losses at each age of assessment within the three climatic chambers to determine a correction factor to estimate the true metabolizable energy of corn..$^{(5)}$

The basal diet was formulated based on corn and soybean meal, and the food composition and nutritional requirements were obtained from Rostagno et al. ${ }^{(6)}$ (Table 1). The test diet was obtained by replacing part of the basal diet with the test food ( $40 \%$ corn $+60 \%$ basal diet).

All animals remained in a hot chamber until six days of age in order not to compromise their initial performance. Then, they were randomly distributed in the three chambers (cold, thermoneutral, and hot). The values of environmental temperature, relative air humidity, and temperature-humidity index (THI), determined in the climatic chambers during the experimental period, are shown in Table 2. The values of environmental temperature and relative air humidity were collected using a thermo-hygrometer, and a globe thermometer was used to calculate THI. The equipment remained inside the climatic chambers throughout the experimental period. Data collection was carried out in the morning and at the end of the day.

Three metabolic tests with four days of adaptation ( 7 to 10,21 to 24 , and 35 to 38 days of age) and four days of total excreta collection (11 to 14,25 to 28 , and 39 to 42 days of age) were performed to assess the use of metabolizable energy and the metabolization of corn nutrients with increasing age. 
Table 1. Composition and calculated values of experimental diets

\begin{tabular}{|c|c|c|c|c|}
\hline \multirow[b]{2}{*}{ Ingredient } & \multicolumn{4}{|c|}{ Raising phase (days old) } \\
\hline & 1 to 7 & 8 to 21 & 22 to 35 & 36 to 42 \\
\hline Corn & 61.175 & 64.910 & 66.600 & 70.600 \\
\hline Soybean meal & 28.300 & 24.710 & 18.000 & 14.520 \\
\hline Meat meal & 2.000 & 2.500 & 5.500 & 5.500 \\
\hline Common salt & 0.240 & 0.220 & 0.170 & 0.160 \\
\hline Vitamin and mineral suppl. & $0.500^{1}$ & $0.400^{1}$ & $0.400^{2}$ & $0.200^{3}$ \\
\hline Calcitic limestone & 0.800 & 0.750 & 0.450 & 0.395 \\
\hline Dicalcium phosphate & 1.450 & 1.150 & 0.250 & 0.120 \\
\hline DL-methionine & 0.185 & 0.130 & 0.130 & 0.130 \\
\hline L-lysine & 0.510 & 0.370 & 0.420 & 0.455 \\
\hline Protenose & 4.500 & 4.510 & 4.770 & 4.700 \\
\hline Sodium bicarbonate & 0.340 & 0.350 & 0.310 & 0.290 \\
\hline Starch & & & 3.000 & 3.130 \\
\hline Total & 100.000 & 100.000 & 100.000 & 100.000 \\
\hline \multicolumn{5}{|l|}{ Calculated values } \\
\hline MB (kcal/kg) & 2950 & 3000 & 3099 & 3152 \\
\hline CP (\%) & 22.04 & 20.79 & 19.42 & 18.55 \\
\hline Calcium (\%) & 0.94 & 0.89 & 0.82 & 0.76 \\
\hline Available phosphorus (\%) & 0.47 & 0.44 & 0.41 & 0.38 \\
\hline Methionine (\%) & 0.52 & 0.48 & 0.43 & 0.41 \\
\hline Methionine + cystine (\%) & 0.82 & 0.74 & 0.70 & 0.67 \\
\hline Lysine (\%) & 1.33 & 1.14 & 1.07 & 1.02 \\
\hline Threonine (\%) & 0.72 & 0.68 & 0.62 & 0.57 \\
\hline Potassium (\%) & 0.73 & 0.69 & 0.61 & 0.56 \\
\hline Sodium (\%) & 0.22 & 0.22 & 0.21 & 0.20 \\
\hline Chlorine (\%) & 0.20 & 0.19 & 0.18 & 0.17 \\
\hline Linoleic acid (\%) & 1.38 & 1.43 & 1.42 & 1.46 \\
\hline
\end{tabular}

TVitamin and mineral supplement Vaccinar Nutrição e Saúde Animal (per $\mathrm{kg}$ of feed): folic acid $1.25 \mathrm{mg}$, pantothenic acid $12.5 \mathrm{mg}$, BHT $2.5 \mathrm{mg}$, biotin $0.125 \mathrm{mg}$, copper $12.5 \mathrm{mg}$, choline $750.0 \mathrm{mg}$, iron $62.62 \mathrm{mg}$, iodine $0.025 \mathrm{mg}$, manganese $67.5 \mathrm{mg}$, niacin $37.5 \mathrm{mg}$, selenium $0.225 \mathrm{mg}$ vitamin A $12,500 \mathrm{IU}$, vitamin B1 $2.5 \mathrm{mg}$, vitamin B12 $25 \mathrm{mg}$, vitamin B2 $5.0 \mathrm{mg}$, vitamin B6 $5.0 \mathrm{mg}$, vitamin D3 $2500 \mathrm{IU}$, vitamin E $25.0 \mathrm{mg}$, vitamin K3 2.5 $\mathrm{mg}$, zinc $68.75 \mathrm{mg}$, avilamycin $7.5 \mathrm{mg}$, monensin $125.0 \mathrm{mg}$. ${ }^{2}$ Vitamin and mineral supplement Vaccinar Nutrição e Saúde Animal (per $\mathrm{kg}$ of feed): folic acid $1.0 \mathrm{mg}$, pantothenic acid $10.0 \mathrm{mg}$, BHT $2.0 \mathrm{mg}$, biotin $0.1 \mathrm{mg}$, copper 10.0 $\mathrm{mg}$, choline $600.0 \mathrm{mg}$, iron $50.1 \mathrm{mg}$, iodine $0.02 \mathrm{mg}$, manganese $54.0 \mathrm{mg}$, niacin $30.0 \mathrm{mg}$, selenium $0.18 \mathrm{mg}$, vitamin A 10,000 IU, vitamin B1 $2.0 \mathrm{mg}$, vitamin B12 $20.0 \mathrm{mg}$, vitamin B2 $4.0 \mathrm{mg}$, vitamin B6 $4.0 \mathrm{mg}$, vitamin D3 $2000 \mathrm{IU}$, vitamin E $20.0 \mathrm{mg}$, vitamin $K 32.0 \mathrm{mg}$, zinc $55.0 \mathrm{mg}$, avilamycin $6.0 \mathrm{mg}$, monensin $100.0 \mathrm{mg}$. Vitamin and mineral supplement Vaccinar Nutrição e Saúde Animal (per $\mathrm{kg}$ of feed): folic acid $0.5 \mathrm{mg}$, pantothenic acid $5.0 \mathrm{mg}$, BHT $1.0 \mathrm{mg}$, biotin $0.05 \mathrm{mg}$, copper $5.0 \mathrm{mg}$, choline $300.0 \mathrm{mg}$, iron $25.05 \mathrm{mg}$, iodine $0.01 \mathrm{mg}$, manganese $27.0 \mathrm{mg}$, niacin $15.0 \mathrm{mg}$, selenium $0,09 \mathrm{mg}$, vitamin A $5,000 \mathrm{IU}$, vitamin $B 11.0 \mathrm{mg}$, vitamin $B 1210.0 \mathrm{mg}$, vitamin $B 22.0 \mathrm{mg}$, vitamin B6 $2.0 \mathrm{mg}$, vitamin D3 1,000 IU, vitamin E $10.0 \mathrm{mg}$, vitamin $\mathrm{K} 31.0 \mathrm{mg}$, zinc $27.5 \mathrm{mg}$, avilamycin $3.0 \mathrm{mg}$, monensin $50.0 \mathrm{mg}$. 
Table 2. Environmental conditions and temperature-humidity index (THI) observed in climatic chambers during the experimental period

\begin{tabular}{lcccccccc}
\hline & \multicolumn{3}{c}{$\begin{array}{c}\text { Environmental } \\
\text { temperature }\left({ }^{\circ} \mathrm{C}\right)\end{array}$} & \multicolumn{2}{c}{ Relative humidity (\%) } & THI \\
\hline Chamber & Minimum & Maximum & Mean & Minimum & Maximum & Mean & Mean \\
Cold & 17.63 & 20.29 & 18.96 & 61.70 & 83.03 & 72.37 & 66.08 \\
Thermoneutral & 24.63 & 26.81 & 25.76 & 59.65 & 76.88 & 68.28 & 75.24 \\
Hot & 29.42 & 31.87 & 30.56 & 48.94 & 62.78 & 55.86 & 82.19 \\
\hline
\end{tabular}

${ }^{1} \mathrm{THI}$ : dry-bulb thermometer temperature $\left({ }^{\circ} \mathrm{C}\right)+\left(0.36 \times\right.$ wet-bulb thermometer temperature $\left.\left({ }^{\circ} \mathrm{C}\right)\right)+41.5 .{ }^{(7)}$

Samples of feed and excreta were stored frozen $\left(-16^{\circ} \mathrm{C}\right)$ for the analyses of dry matter $(D M)$, nitrogen (N), and ether extract (EE), according to the methodology described by Silva \& Queiroz. ${ }^{(8)}$ The results allowed calculating the coefficients of apparent and true metabolizability of dry matter (CMDM and CMDMT), ether extract (CMEE and CMEET), and nitrogen (CMN and CMNT) of the test diet.

The gross energy values of diets and excreta were obtained using an Ika Works C-200 calorimeter, which allowed calculating the apparent and true metabolizable energy (AME and TME), subsequently corrected by the nitrogen balance (AMEn and TMEn) in the natural matter using the equations proposed by Matterson et al. ${ }^{(9)}$ The metabolizability coefficients of food energy were determined based on the values of gross energy, AME, AMEn, TME, and TMEn.

Statistical analyses were performed using analysis of variance by the software SAEG.(10) Significant differences between the means of treatments were verified using the Tukey test (5\% probability).

\section{Results and discussion}

The chemical composition of corn in the natural matter used in the experiment was $87.84 \%$ dry matter, $7.5 \%$ crude protein, 3.4\% ether extract, and $3968 \mathrm{kcal} / \mathrm{kg}$ of crude energy. The protein value obtained for corn was lower than those found by Rodrigues et al. ${ }^{(11)}$ of $8.07 \%$, Mello et al. ${ }^{(12)}$ of $7.91 \%$, and Kato et al. ${ }^{(13)}$ from 8.60 to $9.60 \%$, and higher than those mentioned by D'Agostini et al. ${ }^{(14)}$ of $7.33 \%$ and Nery et al. ${ }^{(15)}$ of $7.26 \%$. The frequency of nitrogen fertilization can influence the crude protein content of the grain. (13) The gross energy was higher than that found by Nery et al. ${ }^{(15)}$ of $3939 \mathrm{kcal} / \mathrm{kg}$ and lower than the result of D'Agostini et al. ${ }^{(14)}$ of $4089 \mathrm{kcal} / \mathrm{kg}$ and Mello et al. ${ }^{(12)}$ of 4009 $\mathrm{kcal} / \mathrm{kg}$. These differences occur because soil fertility, climate, genetics, storage, and processing are factors that interfere with the chemical composition of food. ${ }^{(16)}$

An interaction was observed between environmental temperature and raising phase 
for AME, AMEn, TME, and TMEn (Table 3). Broilers at the growing phase (25 to 28 days of age) raised in the cold chamber used the energy from corn better when compared to animals raised under thermoneutral temperature (AME) $(P=0.0315)$ and better than animals raised under thermoneutral and hot temperature after correction by the nitrogen balance $(P=0.048)$. The correction of endogenous losses (TME and TMEn) canceled the differences between temperatures, with no differences in the metabolizable energies assessed within the raising phases.

Table 3. Slicing of the interaction between raising phase and environmental temperature for the metabolizable energy values of corn $(\mathrm{kcal} / \mathrm{kg})$ expressed in the natural matter for broilers

\begin{tabular}{|c|c|c|c|c|c|}
\hline Temperature & Cold & Thermoneutral & Hot & Mean & $\mathrm{CV}^{\prime}(\%)$ \\
\hline Phase & & ${ }^{2} \mathrm{AME}(\mathrm{kcal} / \mathrm{kg})$ & & & \\
\hline Initial & 3332 & $3288 \mathrm{~b}$ & $3180 \mathrm{~b}$ & 3267 & \\
\hline Growing & $3397 \mathrm{~A}$ & $3191 \mathrm{Bb}$ & $3273 \mathrm{ABb}$ & 3287 & 2.57 \\
\hline Final & 3445 & 3524 a & 3374 a & 3447 & \\
\hline \multirow[t]{2}{*}{ Mean } & 3391 & 3335 & 3275 & & \\
\hline & & ${ }^{2}$ AMEn (kcal/kg) & & & \\
\hline Initial & 3265 & $3246 \mathrm{~b}$ & $3135 b$ & 3215 & \\
\hline Growing & $3322 \mathrm{~A}$ & $3132 \mathrm{Bb}$ & $3200 \mathrm{Bb}$ & 3218 & 2.34 \\
\hline Final & 3379 & 3459 a & $3362 \mathrm{a}$ & 3400 & \\
\hline \multirow[t]{2}{*}{ Mean } & 3322 & 3279 & 3233 & & \\
\hline & & ${ }^{2} \mathrm{TME}$ (kcal/kg) & & & \\
\hline Initial & 3434 & $3375 \mathrm{~b}$ & $3293 \mathrm{~b}$ & 3367 & \\
\hline Growing & 3563 & $3389 \mathrm{~b}$ & $3446 b$ & 3466 & 3.01 \\
\hline Final & 3525 & 3709 a & $3637 a$ & 3624 & \\
\hline \multirow[t]{2}{*}{ Mean } & 3507 & 3491 & 3459 & & \\
\hline & & ${ }^{2}$ TMEn (kcal/kg) & & & \\
\hline Initial & 3336 & $3312 \mathrm{~b}$ & $3226 \mathrm{~b}$ & 3291 & \\
\hline Growing & 3441 & $3286 b$ & $3334 \mathrm{~b}$ & 3354 & 2.88 \\
\hline Final & 3437 & 3593 a & $3549 a$ & 3526 & \\
\hline Mean & 3405 & 3397 & 3369 & & \\
\hline
\end{tabular}

$\mathrm{A}, \mathrm{B}, \mathrm{a}, \mathrm{b}$ Means followed by different uppercase letters in the row and lowercase letters in the column differ from each other $(P<0.05)$ by the Tukey test.

'CV, coefficient of variation.

${ }^{2}$ Apparent (AME) and true metabolizable energy (TME), as well as corrected by the nitrogen balance (AMEn and TMEn). 
Geraert et $a .^{(17)}$ and Faria Filho et $a l^{\left({ }^{(18)}\right.}$ found that the metabolizable energy content of the feed is not changed by the exposure of chickens to heat, while Keshavarz \& Fuller ${ }^{(19)}$ observed higher energy levels and Yamazaki \& Zi-yi(20) found reduced energy levels (12-month-old Leghorn roosters) with increasing temperature. These different results can be attributed to the specific experimental conditions of each study, such as line, nutritional levels, ingredients, sex, and assessment period (age).

An explanation for these findings was proposed by Hai et al.(21), who compared the effect of temperature $\left(5,21\right.$, and $\left.32^{\circ} \mathrm{C}\right)$ on the digestive process of broilers and found that the enzymatic activity of trypsin and amylase decreased due to heat, not being influenced by low temperature. The pair-feeding approach of this experiment allowed the authors to conclude that, although at a low intensity, the food restriction imposed by exposure to heat improved the digestibility of all nutrients in the diet. The occurrence of these antagonistic effects is one of the justifications for the difficulty in finding and accurately predicting the response of broilers to the thermal challenge, in addition to being the cause of many of the discrepant results presented in the literature.

The mean values of the temperature-humidity index (THI) for the thermal comfort range of poultry are between 71 and 76. (22) Therefore, the THI value of 82.19 (Table 2) for the hot chamber shows that the animals were stressed by heat, but it was not enough to affect the use of corn energy. The lower relative humidity $(\mathrm{RH})$ in the hot chamber during the experiment may have reduced the effect of stress.

Another cause of the absence of the effect of heat stress on ME may be due to the low percentage of protein in the diet with $40 \%$ corn (mean of $15 \%$ CP), which promoted a reduction in the caloric increase, usually caused by protein-rich diets. ${ }^{(23)}$ However, even the high-energy feed (3250 kcal) under a heat stress environment did not impede for the broilers to maintain the same feed intake and weight gain adequate at 35 and 42 days of age. ${ }^{(24)}$

The absence of a sanitary challenge in the experiment may also have assisted in maintaining the use of ME even under heat stress. Broilers infected by Salmonella and raised at a temperature of $31^{\circ} \mathrm{C}$ from 35 to 41 days of age presented lower weight gain and feed intake and worse feed conversion. ${ }^{(25)}$

Animals raised in the cold chamber showed no difference between ages (Table 3) for all calculated energies. The results of the thermoneutral and hot chambers showed that older animals (final phase) had better use of the energy from corn than the other ages in the initial and growing phases $(P<0.001)$. This result may be related to the maturation of the gastrointestinal tract, which, according to Uni et al., ${ }^{(26)}$ is established at 16 days of age in broilers.

The determination of the metabolizable energy of feed ingredients before 14 days of age may present lower values than those obtained with older birds, and the metabolizable energy values determined in older broilers may overestimate the availability of energy for younger birds. (27)

Sakomura et al. ${ }^{(28)}$ found a linear increase in the activity of amylase, trypsin, and lipase with the advancing age of broilers ( 1 to 7,8 to 14,15 to 21 , and 22 to 28 days), and the 
phase of the highest increase occurred between the first and second weeks of age, coinciding with the maximum allometric growth of pancreas.

Batal \& Parsons ${ }^{(29)}$ studied the effect of age on carbohydrate digestibility and found that the AMEn values of corn increased from 12 to $15 \%$ with age. In the current study, the increase in AMEn in broilers at 14 days for 42 days of age was around $5.5 \%$. Mello et al. ${ }^{(12)}$ found no differences in the metabolizable energy of corn with increasing age in metabolic assays with broilers from 10 to 17,26 to 33, and 40 to 47 days of age and 25-week old Leghorn roosters.

The results of AMEn found for corn were lower than those presented by the Brazilian Tables for Poultry and Swine ${ }^{(30)}$ (corn with $7.86 \%$ protein and $3364 \mathrm{kcal} / \mathrm{kg}$ in the natural matter), except for broilers raised at cold and thermoneutral temperatures at the final phase (3379 and $3459 \mathrm{kcal} / \mathrm{kg}$ ) for AMEn. However, the values found by Rostagno et al.(30) are compilations of studies with broilers at different ages and roosters. This study showed lower values for heat stress temperature than those found by Rostagno et al. (30) and, therefore, feed formulation for broilers under stress based on metabolizable energy values acquired at thermoneutral temperature can cause a reduction in the animal performance.

Several studies have assessed the energy value of corn. D'Agostini et al. ${ }^{(14)}$ found mean values of AME and AMEn of 3246 and $3235 \mathrm{kcal} / \mathrm{kg}$ in the natural matter, respectively, for corn. Vieira et al. ${ }^{(31)}$ also found that the apparent metabolizable energy, corrected for the mean of corn hybrids, reached $3744 \mathrm{kcal} / \mathrm{kg}$, ranging from 3405 to $4013 \mathrm{kcal} /$ $\mathrm{kg}$ of DM. Generoso et al.(32) found mean values of apparent metabolizable energy, corrected by the nitrogen balance of corn, of 3351 and $3524 \mathrm{kcal} / \mathrm{kg}$ in the natural matter determined in broilers at the growing ( 21 to 30 days of age) and final phases (41 to 50 days), respectively.

The AME values were higher than the AMEn values in all treatments due to the positive nitrogen balance. This characteristic is normal when ME values are determined in growing broilers, as this phase presents higher retention of nitrogen for the deposition of protein tissue. This difference is more pronounced when the correction for endogenous and metabolic losses is performed. ${ }^{(15)}$

The TME values of corn were, on average, 5.3\% higher than the AME values for broilers raised in the hot chamber, a difference higher than that of the other chambers, that is, 3.3 and $4.5 \%$ for the cold and the thermoneutral chambers, respectively. The methodology consisted of total excreta collection, with the animals fed ad libitum and no interference in the intake volume. Consequently, the AME and TME values were similar. However, the reduction in intake due to heat stress in the hot chamber overestimated the result of TME, increasing the difference between AME and TME.

An interaction $(P<0.001)$ was observed between environmental temperature and age of broilers for the apparent and true nitrogen (NB and TNB) and ether extract (EEB and TEEB) balance of the test diet (Table 4). The results at the initial phase (11 to 14 days of age) showed no interference of the environmental temperature for the evaluated variables (NN, TNB, EEB, and TEEB). The apparent and true nitrogen balances were 
higher for broilers stressed by cold at the growing $(P<0.001)$ and final phases $(P<0.001)$. The worst nitrogen balance for broilers under heat stress has occurred due to the lower efficiency of nitrogen retention, with protein metabolization reduced by heat, regardless of sex and diet. ${ }^{(18,33,34,35)}$

Table 4. Slicing of the interaction between the raising phase and environmental temperature for nitrogen balance and ether extract values of the test diet for broilers

\begin{tabular}{|c|c|c|c|c|c|}
\hline Temperature & Cold & Thermoneutral & Hot & Mean & $\mathrm{CV}^{1}(\%)$ \\
\hline Phase & \multicolumn{5}{|c|}{ Apparent nitrogen balance in grams (NB) } \\
\hline Initial & $13.70 \mathrm{c}$ & $13.98 \mathrm{c}$ & $11.83 \mathrm{~b}$ & 13.14 & \\
\hline Growing & $29.71 \mathrm{Aa}$ & $24.44 \mathrm{Ba}$ & $22.27 \mathrm{Ca}$ & 25.47 & 6.00 \\
\hline Final & $26.96 \mathrm{Ab}$ & $21.03 \mathrm{Bb}$ & $12.32 \mathrm{Cb}$ & 20.10 & \\
\hline \multirow[t]{2}{*}{ Mean } & 23.46 & 19.79 & 15.47 & & \\
\hline & \multicolumn{5}{|c|}{ True nitrogen balance in grams (TNB) } \\
\hline Initial & $18.37 \mathrm{C}$ & $17.30 \mathrm{c}$ & $14.80 \mathrm{c}$ & 16.83 & \\
\hline Growing & $45.59 \mathrm{Aa}$ & $38.77 \mathrm{Ba}$ & $31.26 \mathrm{Ca}$ & 38.54 & 4.12 \\
\hline Final & 38.49 Ab & $31.87 \mathrm{Bb}$ & $20.50 \mathrm{Cb}$ & 30.29 & \\
\hline \multirow[t]{2}{*}{ Mean } & 34.15 & 29.31 & 22.18 & & \\
\hline & \multicolumn{5}{|c|}{ Apparent ether extract balance in grams (EEB) } \\
\hline Initial & $33.38 \mathrm{C}$ & $36.36 \mathrm{c}$ & $31.55 \mathrm{~b}$ & 33.76 & \\
\hline Growing & $82.07 \mathrm{Ab}$ & $69.31 \mathrm{Bb}$ & $63.45 \mathrm{Ba}$ & 71.61 & 4.26 \\
\hline Final & $97.41 \mathrm{Aa}$ & $81.30 \mathrm{Ba}$ & $57.79 \mathrm{Ca}$ & 78.83 & \\
\hline \multirow[t]{2}{*}{ Mean } & 70.95 & 62.32 & 50.93 & & \\
\hline & \multicolumn{5}{|c|}{ True ether extract balance in grams (TEEB) } \\
\hline Initial & $34.39 \mathrm{c}$ & $37.144 \mathrm{c}$ & $32.51 \mathrm{~b}$ & 34.68 & \\
\hline Growing & $86.02 \mathrm{Ab}$ & $74.09 \mathrm{Bb}$ & $66.33 \mathrm{Ba}$ & 75.48 & 4.09 \\
\hline Final & $98.58 \mathrm{Aa}$ & $84.14 \mathrm{Ba}$ & $59.71 \mathrm{Ca}$ & 81.48 & \\
\hline Mean & 73.67 & 65.12 & 52.85 & & \\
\hline
\end{tabular}

A similar result was observed for EEB and TEEB, with a worse balance for animals under heat stress. However, broilers raised under thermoneutral temperature at the growing phase had no differences compared to animals raised under hot temperature. Broilers exposed to heat have higher water intake, which can cause less digestibility of nutrients by increasing the feed passage rate. ${ }^{(36)} \mathrm{Heat}$ is also responsible for reducing the size of 
$\operatorname{organs}^{(37)}$ and the surface of intestinal villi. ${ }^{(38)}$

The effect of broiler age within the climatic chambers was better for NB $(P<0.001)$ and the TNB $(P<0.001)$ at all temperatures and the growing phase ( 25 to 28 days of age). Proteins are essential in the nutritional and metabolic aspects for broilers, as they are related to body processes such as the formation of structural tissues (muscle). Protein deposition in skeletal muscles in growing animals contributes about $65 \%$ of all protein deposited daily. ${ }^{(39)}$

Older broilers had the highest EEB and TEEB (cold and thermoneutral temperature), not differing from the growing phase for heat-stressed broilers. The presence of substrate in the digestive tract in young broilers seems to induce a higher production of enzymes. Thus, the activity of digestive enzymes, both pancreatic and membrane, increases with the broiler age, reaching higher levels at 10 days of age, on average. ${ }^{(40)}$ Rapid changes in the digestive tract enable an increase in feed intake and alter nutrient digestibility. (4) The higher ether extract balance obtained in broilers at the final phase was probably due to the higher production of enzymes for digesting lipids compared to the young animals.

A significant interaction between temperature and age was observed for the variables CMDM ( $P=0.0130)$, CMDMT $(P=0.0150), C M N(P<0.001), C M N T(P<0.001)$, and CMEE $(P<0.001)$, except for $C M E E T$, which presented an exclusive effect of the raising phase $(\mathrm{P}=0.0404)$ (Table 5).

The best metabolization of dry matter in the feed at the initial phase was observed for broilers under thermoneutral temperature, but broilers under cold stress showed better results with the increase of age, not differing from the thermoneutral temperature at the final phase. The temperature did not affect the results of broilers at the initial phase when CMDM was corrected for endogenous losses (CMDMT), with the best coefficients for birds raised in the thermoneutral chamber at the final phase, not differing from the cold chamber at the growing phase.

The use of nitrogen (CMN) showed an interference of temperature only for older broilers, in which heat stress reduced nitrogen use. A temperature effect was observed for all age phases when endogenous losses (CMNT) were removed. Broilers at the initial phase showed better coefficients when raised under cold stress, not differing from the thermoneutral temperature at the growing phase. Heat or cold stress in older broilers reduced nitrogen uptake.

The ability of broilers to deal with oxidative stress gradually decreases as the environmental temperature increases. ${ }^{(41)}$ These negative effects also interfere with the intake of feed and nutrients ${ }^{(4)}$ and, consequently, nutrient use is reduced.

CMEE was not influenced by the temperature at the growing phase $(P=0.5316)$. Cold stress for young broilers caused a reduction in the coefficient, with the best results for older broilers (final phase) raised at thermoneutral temperature. When CMEE was corrected by endogenous losses (CMEET), only the age effect influenced this variable, confirming better use of the ether extract by older broilers. 
Table 5. Slicing of the interaction between raising phase and environmental temperature for the coefficient of metabolizability of nutrients (\%) in the test diet for broilers

\begin{tabular}{|c|c|c|c|c|c|}
\hline Temperature & Cold & Thermoneutral & Hot & Mean & $\mathrm{CV}^{1}(\%)$ \\
\hline Phase & \multicolumn{5}{|c|}{ Coefficient of apparent metabolizability of dry matter (CMDM) } \\
\hline Initial & $77.90 \mathrm{BC}$ & $78.72 \mathrm{Ab}$ & $77.43 \mathrm{~B}$ & 78.02 & \\
\hline Growing & $79.96 \mathrm{Ab}$ & $78.51 \mathrm{Bb}$ & $78.52 \mathrm{~B}$ & 79.00 & 0.82 \\
\hline Final & $81.16 \mathrm{Aa}$ & $82.17 \mathrm{Aa}$ & $78.52 \mathrm{~B}$ & 80.62 & \\
\hline \multirow[t]{2}{*}{ Mean } & 79.68 & 79.80 & 78.15 & & \\
\hline & \multicolumn{5}{|c|}{ Coefficient of true metabolizability of dry matter (CMDMT) } \\
\hline Initial & $81.14 \mathrm{~b}$ & $81.40 \mathrm{c}$ & $80.75 \mathrm{c}$ & 81.09 & \\
\hline Growing & 85.96 Aa & $86.52 \mathrm{Ab}$ & $84.05 \mathrm{Bb}$ & 85.51 & 0.78 \\
\hline Final & $85.74 \mathrm{Ba}$ & $88.16 \mathrm{Aa}$ & $85.60 \mathrm{Ba}$ & 86.50 & \\
\hline \multirow[t]{2}{*}{ Mean } & 84.28 & 85.36 & 83.47 & & \\
\hline & \multicolumn{5}{|c|}{ Coefficient of apparent metabolizability nitrogen (CMN) } \\
\hline Initial & 54.34 b & $55.64 \mathrm{~b}$ & 52.08 b & 53.85 & \\
\hline Growing & $58.51 \mathrm{a}$ & $56.64 \mathrm{~b}$ & $58.25 \mathrm{a}$ & 57.80 & 4.36 \\
\hline Final & $59.44 \mathrm{Aa}$ & $59.84 \mathrm{Aa}$ & $48.26 \mathrm{Bb}$ & 55.85 & \\
\hline \multirow[t]{2}{*}{ Mean } & 57.43 & 57.20 & 52.86 & & \\
\hline & \multicolumn{5}{|c|}{ Coefficient of true metabolizability of nitrogen (CMNT) } \\
\hline Initial & $72.89 \mathrm{AC}$ & $68.70 \mathrm{Bb}$ & $65.18 \mathrm{Cb}$ & 68.92 & \\
\hline Growing & $89.84 \mathrm{Aa}$ & $89.90 \mathrm{Aa}$ & $81.77 \mathrm{Ba}$ & 87.17 & 3.09 \\
\hline Final & $84.91 \mathrm{Bb}$ & $90.78 \mathrm{Aa}$ & $80.84 \mathrm{Ba}$ & 85.51 & \\
\hline \multirow[t]{2}{*}{ Mean } & 82.55 & 83.12 & 75.93 & & \\
\hline & \multicolumn{5}{|c|}{ Coefficient of apparent metabolizability of ether extract (CMEE) } \\
\hline Initial & $79.79 \mathrm{Bb}$ & $84.20 \mathrm{Ab}$ & $81.25 \mathrm{Ab}$ & 81.75 & \\
\hline Growing & $82.52 \mathrm{~b}$ & $81.46 \mathrm{~b}$ & $84.57 \mathrm{~b}$ & 82.85 & 1.27 \\
\hline Final & $86.39 \mathrm{Ba}$ & $92.27 \mathrm{Aa}$ & $88.44 \mathrm{Ba}$ & 86.39 & \\
\hline \multirow[t]{2}{*}{ Mean } & 82.90 & 85.98 & 84.75 & & \\
\hline & \multicolumn{5}{|c|}{ Coefficient of true metabolizability of ether extract (CMEET) } \\
\hline Initial & 82.22 & 86.01 & 83.71 & $83.98 \mathrm{c}$ & \\
\hline Growing & 86.49 & 87.07 & 88.42 & $87.33 \mathrm{~b}$ & 1.27 \\
\hline Final & 89.21 & 95.50 & 91.38 & $92.03 \mathrm{a}$ & \\
\hline Mean & 85.97 & 89.53 & 87.83 & & \\
\hline
\end{tabular}


Garcia et al. ${ }^{(42)}$ worked with the digestibility of diets containing sorghum with low or high tannin for colostomized (removal of the colon via surgery and collection of feces and uric acid separately) broilers raised at three environmental temperatures (14, 25, and 32 ${ }^{\circ} \mathrm{C}$ ) and found that the coefficients of digestibility of dry matter and ether extract were higher in the hot chamber and lower in the cold. These higher values were associated with the lower intake observed at high temperatures, which led to a lower speed of transit of food in the digestive tract of broilers and, consequently, higher absorption of nutrients. ${ }^{(4)}$ This result occurred in the current study only for CMEE at the initial phase.

There was an effect of the broiler age for the studied temperatures. The best results for CMDM were observed in broilers at the final phase raised under thermoneutral and cold temperatures. Broilers in the hot chamber used the dry matter similarly, regardless of age. After correction (CMDMT), the results in the thermoneutral chamber were maintained, not differing between broilers at the growing and final phase in the cold chamber. Age also interfered with CMDMT for broilers in the hot chamber, with better results at the final stage.

Nitrogen metabolization (CMN) was better for broilers at the final phase in the thermoneutral chamber and growing and final phases in the cold chamber. The best coefficients under heat stress were observed in broilers at the growth phase (25 to 28 days of age). The correction for endogenous losses (CMNT) did not change the results inside the chambers, and broilers in the cold, thermoneutral, and hot chambers had the lowest coefficients at the initial phase, but the growing phase in the cold chamber had the best result.

The ether extract was better used by older broilers, regardless of the environmental temperature. Broiler age not only interfered with the metabolizable energy but also with the metabolizability of nutrients in the diet. Furthermore, heat stress reduced the metabolizability of nutrients in the test diet.

Bonnet et al. $^{(36)}$ conducted a performance experiment and metabolic test using broilers from 38 to 42 days of age raised under hot $\left(32{ }^{\circ} \mathrm{C}\right)$ and thermoneutral temperature $(22$ $\left.{ }^{\circ} \mathrm{C}\right)$, fed ad libitum, and pair-feeding (controlled feeding). The authors observed that, even with the same intake, broilers submitted to heat stress did not obtain the same growth rate as the animals under a thermoneutral environment. Also, a reduction in feed efficiency was observed during heat stress as a direct consequence of exposure to high temperature.

\section{Conclusions}

In general, the metabolizable energy values of corn, the balances, and coefficients of metabolizability of nutrients in the test diet increased with the broiler age, but the true metabolizable energy of corn was not affected by the environmental temperature. The balances and coefficients of metabolizability of nutrients in the test diet were reduced under heat stress for broilers at the growing and final phases. 


\section{Acknowledgments}

To the São Paulo Research Foundation - FAPESP for financial support for conducting this research.

\section{Conflict of interest}

The authors declare no conflict of interest.

\section{References}

1. Saeeda M, Abbasc G, Alagawanyd M, Kambohe AA, El-Hackd MEA, Khafagaf AF, Chaoa S. Heat stress management in poultry farms: A comprehensive overview. Journal of Thermal Biology [Internet]. 2019 [cited 2021 January 06]; 84, 414-425, Available from: https://www.sciencedirect.com/science/article/pii/ S0306456519300658?via\%3Dihub. English.

2.Bertechini AG, Fassani EJ, Fialho ET. Utilização do milho QPM (quality protein maize) para aves. Ciência e Agrotecnologia, v. 23, n. 2, p. 434-440, 1999. Portuguese.

3. Murawska D. The Effect of Age on Growth Performance and Carcass Quality Parameters in Different Poultry Species. In: Manafi M. editor. Poultry Science. [Internet]. 2017 [cited 2021 January 05]; 33-50. Available from: https://www.intechopen.com/books/poultry-science/the-effect-of-age-on-growthperformance-and-carcass-quality-parameters-in-different-poultry-species. English.

4.Syafwan S, Wermink GJD, Kwakkel RP, Verstegen MWA. Dietary self-selection by broilers at normal and high temperature changes feed intake behavior, nutrient intake, and performance. Poultry Science [Internet]. 2012 March [cited 2019 Dec 10]; 91(3): 537-549. Available from: https://www.sciencedirect. com/science/article/pii/S0032579119402162. English.

5. Sakomura NK, Rostagno HS. Métodos de pesquisa em nutrição de monogástricos. Jaboticabal: Funep, 2007, 283p.

6.Rostagno, HS, Albino LFT, Donzele JL, Gomes PC, Oliveira R FM, Lopes DC, Ferreira AJP, Toledo Barreto SL. Tabelas brasileiras para aves e suínos: composição de alimentos e exigências nutricionais. 2 st ed. Viçosa: UFV; 2005. 186p. Portuguese.

7.Thom EC. Cooling degree: dayair conditioning, heating, and ventilating. Transaction of the American Society of Heating. 1958; 55(7):65-72.

8.Silva DJ, Queiroz AC. Análise de alimentos: Métodos químicos e biológicos. 3st ed. Viçosa: UFV; 2002. 235p. Portuguese.

9.Matterson LD, Potter LM, Stutz NW, Singsen EP. The metabolizable energy of feeds ingredients for chickens. Storrs, Connecticut : University of Connecticut - Agricultural Experiment Station; 1965. p. 3-11. (Research Report, 7).

10.Saeg - Sistema de análises estatísticas e genéticas: user guide [CD-ROM] Version 9.1: Universidade Federal de Viçosa, UFV, 2007.

11.Rodrigues PB, Rostagno HS, Albino LFT, Gomes PC, Barboza WA, Santana RT. Valores Energéticos do Milheto, do Milho e Subprodutos do Milho, Determinados com Frangos de Corte e Galos Adultos. Revista Brasileira de Zootecnia [Internet]. 2001 Nov [cited 2019 oct 12]; 30(6): 1767-1778. Available from: https:// www.scielo.br/scielo.php?script=sci_arttext\&pid=S1516-35982001000700015\&lng=en\&nrm=iso\&tlng= 


\section{pt. Portuguese.}

12. Mello HHC, Gomes PC, Rostagno HS, Albino LFT, Souza RM, Calderano AA. Valores de energia metabolizável de alguns alimentos obtidos com aves de diferentes idades. [Metabolizable energy values of feedstuffs obtained from poultry at different ages] Revista Brasileira de Zootecnia [Internet]. 2009 May [cited 2019 oct 12]; 38(5): 863-868. Available from: https://www.scielo.br/scielo.php?script=sci arttext\&pid=S1516-35982009000500012\&lng=en\&nrm=iso. Portuguese.

13. Kato KR, Bertechini AG, Fassani EJ, Brito JAG, Castro SF. Metabolizable energy of corn hybrids for broiler chickens at different ages. [Energia metabolizável de milhos híbridos para frangos de corte em diferentes idades] Ciência Agrotécnica [Internet]. 2011 Dec [cited 2019 July 22]; 35(6): 1218-1226. Available from: https://www.scielo.br/scielo.php?script=sci_arttext\&pid=S1413-70542011000600024. English.

14.D’Agostini P, Gomes PC, Albino LFT, Rostagno HS, Sá LM. Valores de composição química e energética de alguns alimentos para aves. [Values of chemical and energy composition of some feedstuffs for broiler chicks]. Revista Brasileira de Zootecnia [Internet]. 2004 Jan [cited 2019 july 21];33(1): 128-134. Available from: https://www.sciencedirect.com/science/article/pii/S0032579119411760?via\%3Dihub. Portuguese.

15.Nery LR, Albino LFT, Rostagno HS, Campos AMA, Silva CR. Valores de energia metabolizável de alimentos determinados com frangos de corte. [Metabolizable energy values of feedstuffs obtained from poultry at different ages] Revista Brasileira de Zootecnia [Internet]. 2007 Sept [cited 2019 oct 12]; 36(5): 1354-1358. Available from: https://www.scielo.br/scielo.php?script=sci_arttext\&pid=S1516-35982007000600018\&ln g=en\&nrm=iso\&tlng=pt. Portuguese.

16.Butolo JE. Qualidade de ingredientes na alimentação animal. Campinas: J.E Butolo, 2002. 430p.

17.Geraert PA, Guillaumin S, Zuprizal LM. Effect of high ambient temperature on dietary ME value in genetically lean and fat chickens. Poultry Science [Internet]. 1992 Dec [cited 2019 Nov 14]; 71(12): 21132116. Available from: https://www.sciencedirect.com/science/article/pii/S0032579119337812. English.

18.Faria Filho DE, Campos DMB, Afonso-Torres KA, Vieira BS, Rosa PS, Vaz AM, Macari M, Furlan RL. Protein levels for heat-exposed broilers: performance, nutrient digestibility, and protein and energy metabolism. International Journal of Poultry Science [Internet]. 2007 [cited 2019 oct 29]; 6(3): 187-194. Available from: https://pdfs.semanticscholar.org/206b/453009848a1c221a8a193c72723655c1f99f.pdf. English.

19.Keshavarz K, Fuller HL. The influence of widely fluctuating temperatures on heat production and energetic efficiency of broilers. Poultry Science [Internet]. 1980 Sept [cited 2019 Dec 10]; 59(9): 21212128. Available from: https://www.sciencedirect.com/science/article/pii/S0032579119356536. English.

20.Yamazaki M, Zi-Yi Z. A note on the effect of temperature on true and apparent metabolizable energy values of a layer diet. British Poultry Science [Internet]. 1982 Nov [cited 2019 Nov 14]; $23(1): 447-450$. Available from: https://www.tandfonline.com/doi/pdf/10.1080/00071688208447977?needAccess=true. English.

21. Hai L, Rong D, Zhang Z-Y. The effect of environment on the digestion of broilers. Journal of Animal Physiology and Animal Nutrition [Internet]. 2001 Dec [cited 2019 July 22]; 83(2): 57-64. Available from: https://www.researchgate.net/publication/229449543 The_effect_of thermal_environment_on the_ digestion of broilers. English.

22.Silva MAN, Barbosa Filho AD, Rosário MF, Silva CJM, Silva IJO, Savino VJM, Coelho AAD. Fatores de estresse associados à criação de linhagens de avós de frangos de corte. [Environmental influence on the performance of parental lines of broiler chicken] Revista Brasileira de Zootecnia [Internet]. 2007 June [cited 2019 oct 12]; 36(3): 652-659. Available from: https://www.scielo.br/scielo.php?script=sci arttext\&pid=S1516-35982007000300019\&lng=en\&nrm=iso\&tlng=pt. Portuguese.

23. Mcleod MG. Effects of amino acid balance and energy: protein ratio on energy and nitrogen metabolism in male broiler chicken. British Poultry Science. 1997; 38:405-411. 
24. Melo FVST, Souza ARL, Cruz Neto MA, Mendes DB, Melo JFB. Níveis de energia metabolizável para frangos de corte em estresse térmico. [Metabolisable energy levels for stress broilers under thermal stress] Revista Brasileira de Saúde e Produção Animal [Internet]. 2020 [cited 2021 January 05]; 21: 01-13. Available from: https://www.scielo.br/scielo.php?script=sci_abstract\&pid=S1519-99402020000100800\&lng=en\&nr $\underline{m=i s o \& t l n g=p t}$. Portuguese.

25.Quinteiro Filho WM, Gomes AVS, Pinheiro ML, Ribeiro A, Ferraz de Paula V, Astolfi Ferreira CS, Ferreira AJP, Palermo Neto J. Heat stress impairs performance and induces intestinal inflammation in broiler chickens infected with Salmonella Enteritidis. Avian Pathology [Internet]. 2012 [cited 2021 January 05]; 41:5, 421-427, Available from: https://www.researchgate.net/publication/230695770 Heat stress impairs_performance and induces_intestinal_inflammation_in_broiler_chickens infected with Salmonella Enteridis. English.

26.Uni, Z.; Ganot, S.; Sklan, D. Posthatch development of mucosal function in the broiler small intestine. Poultry Science [Internet]. 1998 January [cited 2019 Dec 10]; 77(1): 75-82. Available from: https://www. sciencedirect.com/science/article/pii/S0032579119407700?via\%3Dihub\#! English.

27.Yang Z, Pirgozliev VR, Rose SP, Woods P, Yang HM, Wang ZY, Bedford DMR. Effect of age on the relationship between metabolizable energy and digestible energy for broiler chickens. Poultry Science [Internet]. 2020 January [cited 2020 April 29]; 99(1): 320-330. Available from: https://pdfs.semanticscholar. org/206b/453009848a1c221a8a193c72723655c1f99f.pdf. English.

28.Sakomura NK, Del Bianchi M, Pizauro Jr JM, Café MB, Freitas ER. Efeito da idade dos frangos de corte na atividade enzimática e digestibilidade dos nutrientes do farelo de soja e da soja integral. [Effect of age on enzyme activity and nutrients digestibility for broilers fed soybean meal and full fat soybean] Revista Brasileira de Zootecnia [Internet]. 2004 July [cited 2019 oct 12]; 33(4): 924-935. Available from: https:// www.scielo.br/scielo.php?pid=S1516-35982004000400013\&script=sci_arttext\&tlng=en. Portuguese.

29.Batal AB, Parsons CM. Utilization of various carbohydrate sources as affected by age in the chick. Poultry Science [Internet]. 2004 July [cited 2019 Oct 10];83(7): 1140-1147. Available from: https://www. sciencedirect.com/science/article/pii/S0032579119426667. English.

30.Rostagno HS, Albino LFT, Hannas MI, Donzele JL, Sakomura NK, Perazzo FG, Saraiva A, Teixeira ML, Rodrigues PB, Oliveira RF, Barreto SLT, Brito CO. Tabelas brasileiras para aves e suínos: composição de alimentos e exigências nutricionais. 4st ed. Viçosa: UFV; 2017. 488p. Portuguese.

31.Vieira RO, Rodrigues PB, Freitas RTF, Nascimento GAJ, Silva EL, Hespanhol R. Composição química e energia metabolizável de híbridos de milho para frangos de corte. [Chemical composition and metabolizable energy of corn hybrids for broilers] Revista Brasileira de Zootecnia [Internet]. 2007 July [cited 2019 oct 12]; 36(4): 832-838. Available from: https://www. scielo.br/scielo.php?pid=S1516-35982004000400013\&script=sci_arttext\&tlng=en. Portuguese.

32.Generoso RAR, Gomes PC, Rostagno HS, Albino LFT, Barreto SLT, Brumano G. Composição química e energética de alguns alimentos para frangos de corte em duas idades. [Chemical and energy composition of some feeds for broiler chicks and two ages] Revista Brasileira de Zootecnia [Internet]. 2008 July [cited 2019 oct 12]; 37(7): 1251-1256. Available from: https:// www.scielo.br/scielo.php?script=sci arttext\&pid=S1516-35982008000700016\&lng=en\&nrm=is o\&tlng=pt. Portuguese.

33.Faria Filho DE, Rosa OS, Figueiredo DF, Dahlke F, Macari M, Furlan RL. Dietas de baixa proteína no desempenho de frangos criados em diferentes temperaturas. [Low-protein diets on broilers performance reared under different temperatures]. Pesquisa Agropecuária Brasileira [Internet]. 2006 Jan [cited 2019 june 03];41(1): 101-106. Available from: https://www. scielo.br/scielo.php?script=sci_arttext\&pid=S0100-204X2006000100014\&lng=en\&nrm=iso\&tln $\mathrm{g}=\mathrm{pt}$. Portuguese. 
34.Temim S, Chagneau AM, Guillaumin S, Michel J, Peresson R, Geraert PA, Tesseraud S. Effects of chronic heat exposure and protein intake on growth performance, nitrogen retention and muscle development in broiler chickens. Reproduction, Nutrition, Development [Internet]. 1999 [cited 2019 Oct 10]; 39(1): 145-156. Available from: https://hal.archives-ouvertes.fr/hal00900289/document. English.

35.Zuprizal ML, Chagneau AM, Geraert PA. Influence of ambient temperature on true digestibility of protein and amino acid of rapeseed and soybean meals in broilers. Poultry Science [Internet]. 1993 February [cited 2019 Dec 10]; 72(2): 289-295. Available from: https://www.sciencedirect. com/science/article/pii/S0032579119338337\#!. English.

36.Bonnet S, Geraert PA, Lessire M, Carre B, Guillaumin S. Effect of high ambient temperature on feed digestibility in broiler. Poultry Science [Internet]. 1997 June [cited 2019 july 10];76(6): 857-863. Available from: https://www.sciencedirect.com/science/article/pii/ S0032579119411760?via\%3Dihub. English

37.Savory CJ. Influence of ambient temperature on feeding activity parameters and digestive function in domestic fowls. Physiology Behavior [Internet]. 1986 [cited 2019 Dec 10]; 38(3): 353357. Available from: https://www.sciencedirect.com/science/article/pii/003193848690106X. English.

38. Mitchell MA, Carlisle AJ. The effects of chronic exposure to elevated environmental temperature on intestinal morphology and nutrient absorption in the domestic fowl (Gallus domesticus). Comparative Biochemestry and Physiology Part A: Physiology [Internet]. 1992 Jany [cited 2019 Dec 10]; 101(1): 137-142. Available from: https://www.sciencedirect.com/science/ article/pii/0300962992906413?via\%3Dihub. English.

39.Macari M, Furlan RL, Gonzales E. Fisiologia Aviária: Aplicada a frangos de corte. 2st ed., Jaboticabal: FUNEP; 2002. 375p. Portuguese.

40.Noy Y, Sklan D. Posthatch development of poultry. Journal of Applied Poultry Research [Internet]. 1997 Oct [cited 2019 Dec 10]; 6(3): 344-354. Available from: https://www.sciencedirect. com/science/article/pii/S0032579119356536. English.

41.Wang Y, Xia L, Guo T, Cheng C, Jiang L, Wang D, Wang J, Li K, Zhan X. Metabolic changes and physiological responses of broilers in the final stage of growth exposed to different environmental temperatures.PoultryScience[Internet].2020April[cited 2020April29]; 99(4):2017-2025.Available from: https://pdfs.semanticscholar.org/206b/453009848a1c221a8a193c72723655c1f99f.pdf. English.

42.Garcia RG, Mendes AA, Klink UP, Almeida Paz ICL, Takahashi SE, Pelícia K, Komiyama M, Quinteiro RR. Digestibilidade de rações contendo sorgo com e sem tanino em frangos de corte colostomizados submentidos a três temperaturas ambiente. [Digestibility of feeds containing sorghum, with and without tannin, forcolostomyzed broiler chickens submitted to three room temperature] ARS Veterinária [Internet]. 2005 [cited 2019june 17]; 21(2):257-264. Available from: https://www.researchgate.net/publication/277120596_DIGESTIBILIDADE_DE_RACOES CONTENDO_SORGO_COM_E_SEM_TANINO_EM_FRANGOS_DE_CORTE_COLOSTOMIZADOS SUBMETIDOS_A_TRES_TEMPERATURAS_AMBIENTE. Portuguese. 